\title{
KaJian PerencanaAn Kota Pada Gedung Bekas RSJ MANGUNJAYAN, SRIWEdARI, SURAKARTA
}

\author{
KUSUMASTUTI \\ PROGRAM STUdi PERENCANAAN WILAYAH DAN KotA, \\ FAKULTAS TEKNIK \\ Universitas Sebelas Maret, SuRaKarta
}

\begin{abstract}
Kota dan bagian-bagiannya adalah suatu sistem tatanan yang menggambarkan bagaimana pandangan hidup masyarakatnya ditata dan tercermin dalam penggunaan ruang-ruang kotanya. Banyak hal bisa dibaca dari tatanan ruang sebuah kota, mulai dari kerjasama ataupun konflik dari berbagai kelompok yang mendiaminya, hubungan masyarakat warga dan elit-elitnya serta struktur ekonomi dari kehidupan kota dan faktorfaktor kehidupan yang mempengaruhi perkembangan kota tersebut.

Kajian ini akan melihat bagaimana konstelasi hubungan dan posisi bangunan-bangunan di dalam ruang Kota Surakarta, khususnya hubungan antara berbagai peristiwa dengan pembangunan eks bangunan RSJ Mangunjayan, Taman Sriwedari dan RS Kadipolo pada era pemerintahan Paku Buwono X. Metode yang digunakan adalah deskriptif, yaitu menjabarkan suatu keadaan melalui studi literature terhadap tulisan, fakta sejarah, foto dan peta yang berhubungan dengan pembangunan RSJ Mangunjayan dan menggambarkan kedudukan RSJ Mangunjayan di dalam struktur Kota Kolonial di Surakarta pada masa itu.
\end{abstract}

Keywords: perencanaan kota, RSJ Mangunjayan

\section{KONSEP KOTA}

Pengertian kota menurut Kamus Besar Bahasa Indonesia (KBBI) tahun 1989 adalah daerah yang merupakan pusat kegiatan pemerintahan, ekonomi dan kebudayaan. Sementara itu Hablin (dalam Adrisijanti, 2000) menyatakan bahwa kota adalah tempat yang dihuni secara permanen oleh suatu kelompok yang lebih besar dari suatu klen dan terdapat suatu pembagian kerja, yang kemudian melahirkan kelompok-kelompok sosial dengan diferensiasi fungsi, hak, dan tanggung-jawab. Selanjutnya Jones (1966, dalam Adrisijanti, 2000) menambahkan bahwa kota juga menyangkut unsur keluasan wilayah, kepadatan penduduk yang bersifat heterogen dan bermata-pencaharian non-pertanian, serta fungsi administratif, ekonomi dan budaya yang secara keseluruhan terwujud dalam fisik dan bentuk kota.

Pertumbuhan dan perkembangan suatu kota tidak lepas dari faktor politis, ekonomis, geografis, kosmologis dan magis-religius (Tjandrasasmita, 1975, dalam Adrisijanti, 2000). Walaupun demikian pada dasarnya kota memiliki ciri-ciri universal yang berhubungan dengan asal pertumbuhan, lokasi, ekologi dan unsur sosialnya. Sementara itu, faktor-faktor ekonomi, politik, teknologi, dan sosial sering dianggap mendasari tumbuhnya suatu kota (Adrisijanti, 2000).

\section{KOTA SURAKARTA SEBAGAI KOTA PUSAT PEMERINTAHAN KERAJAAN DI JAWA}

Pertumbuhan Kota Surakarta sebagai kota pusat pemerintahan Kerajaan Mataram Islam dipengaruhi oleh asal pertumbuhan kota sebagai bandar perdagangan yang berlokasi ditepi Sungai Bengawan Solo. Sebagai bandar perdagangan maka Kota Surakarta berfungsi sebagai urat nadi perdagangan Jawa Tengah dan Jawa Timur sejak Majapahit yang menggunakan sungai sebagai transportasi utama. Karena fungsi-fungsi tersebut maka tumbuhlah masyarakat dagang di Kota Surakarta. Pada perkembangan selanjutnya, kekuatan politik masuk dalam kepentingankepentingan perdagangan dunia sehingga mempengaruhi tumbuh dan berkembangnya kekuatan yang menguasai sumber-sumber daya alam yang melimpah di Pulau Jawa dan wilayah Kerajaan Mataram pada khususnya. Kekuatankekuatan ini mempengaruhi perkembangan Kota Surakarta bahkan kota-kota kabupaten (regensi) di pulau Jawa. Di Surakarta, hegemoni kekuatan dan kekuasaan Kerajaan Mataran Islam secara perlahan diambil alih 
oleh Pemerintah Kolonial Belanda. Hal tersebut dapat dilihat pada struktur tata ruang Kota Surakarta pada masa itu bahwa sebagian besar dibuat untuk kepentingan Pemerintah Kolonial Belanda. Meskipun struktur tata ruang kerajaan masih dipergunakan juga sebagai wujud kekuasaan Kerajaan Mataram Islam di Surakarta.

Komponen-komponen kota pusat pemerintahan Kerajaan Mataram-Islam dari Demak, Kota-Gede, Pajang, Kartasura hingga kemudian Surakarta dapat dikelompokkan menjadi dua, yaitu komponen pokok dan penunjang (Adrisijanti,2000). Komponen pokok tersebut berkaitan dengan kebutuhan hidup manusia yang dikelompokkan menurut fungsinya sebagai berikut:

1) Fungsi tempat tinggal

a. Kraton beserta alun-alunnya sebagai tempat tinggal raja dan keluarga terdekat, disebut sebagai kota inti.

b. Pemukiman lain yang dibagi menjadi dua macam, yaitu:

Dalem bagi golongan
bangsawan dan elit birokrat yang
berlokasi di situs-situs yang
memiliki nama dalam toponimi.
$\checkmark$
Pemukiman bagi rakyat
kebanyakan (non-elit) yang
terletak di lokasi dengan nama
toponimi.

2) Fungsi keamanan yang tercermin dalam tiga komponen, yakni benteng luar, jagang, dan jaringan jalan.

3) Fungsi ekonomi tercermin dari keberadaan pasar, jaringan jalan, serta toponimi yang menunjukkan jenis-jenis profesi.

4) Fungsi religi tercermin dari keberadaan masjid, toponimi yang menggambarkan profesi keagamaan, pemakaman, dan alunalun.

5) Fungsi rekreasi tercermin dari adanya taman dan krapyak, meskipun dalam hal penggunaannya kedua komponen tersebut tampaknya tidak diperuntukkan bagi semua lapisan penghuni kota.

Adapun komponen penunjang adalah komponen yang bersifat melengkapi namun tidak vital, atau merupakan perkembangan baru yang tidak selalu muncul pada setiap kota-kota kerajaan Mataram Islam berupa pintu gerbang pabean, loji dan benteng VOC, serta lumbung.

Komponen-komponen pokok dan penunjang pada pusat Kerajaan Mataram Surakarta tersebut, yang tercermin pada fungsi dari masing-masing komponen, menggunakan konsep kosmologi Jawa yang ditafsirkan secara filosofis-religius, politis, ekonomis dan budaya. Kosmologi adalah suatu tatanan kota yang menselaraskan antara dunia manusia (mikrokosmos) dengan jagat raya (makrokosmos). Pada struktur tata ruang ibukota Kerajaan Mataram Islam di Surakarta yang disebut sebagai Kuthanegara, tradisi Hindu dan Budha sangat kental mempengaruhi. Hal tersebut dapat dilihat bahwa struktur tata ruang Kuthanegara, dalam hal ini hierarkhi dan hubungan antar ruang sangat dipengaruhi oleh upacara ritual dan simbol-simbolnya. Selain itu, tata ruang Kota Surakarta sangat berhubungan dengan struktur sosial masyarakat Jawa. Raja bertempat tinggal di dalam Kraton (istana) yang terletak dipusat kota kerajaan. Pusat ini dikelilingi oleh para pemuka agama (ulama) dan para pemimpin kerajaan (sentono dalem) lingkaran berikutnya adalah abdi dalem (pelayan), prajurit (tentara), dan para seniman (pengrajin). Sementara itu di luar kota tinggallah para pedagang dan petani. Hal itu menggambarkan bahwa struktur dari kosmos dimana Dewa/Tuhan ada di tengah-tengah dikelilingi rakyat kebanyakan atau rakyat jelata.

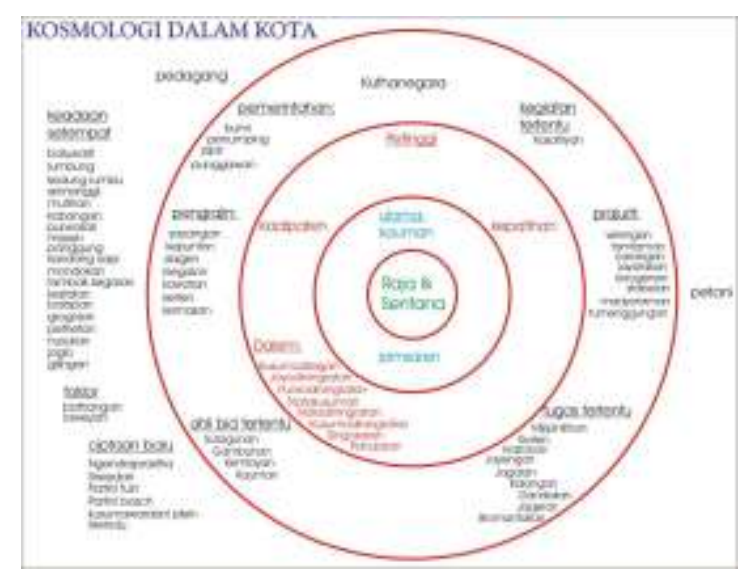

Gambar 1: Kosmologi dalam Struktur

Kota Pusat Kerajaan Kasunanan Surakarta (Sumber: Solo Heritage Society, 2003) 


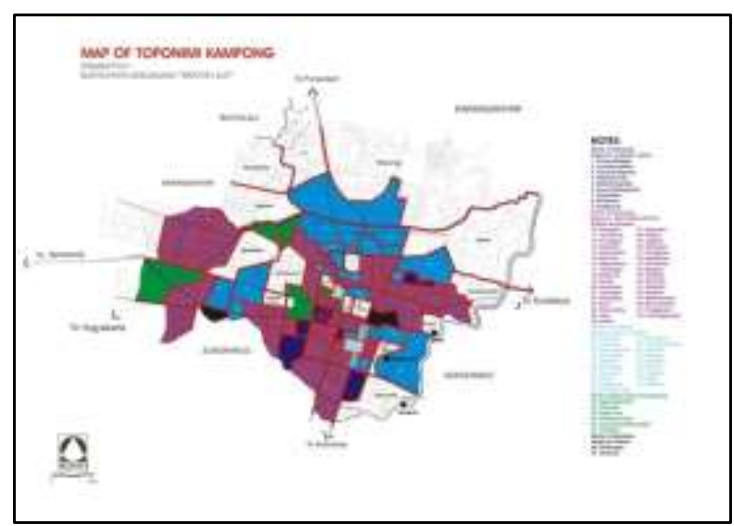

Gambar 2: Peta Toponimi Kampung di Kota Surakarta

(Sumber: Muladi dkk, 1999)

Kota sebagai suatu kesatuan dipandang merupakan suatu sistem, maka kraton dan alunalun dapat dikatakan sebagai suatu sub-sistem yang merupakan nucleus atau inti kota. Inti tersebut secara fisik dinyatakan dalam bentuk kawasan yang dikelilingi oleh benteng atau baluwarti. Maka skema denah kota-kota Mataram Islam adalah empat persegi panjang konsentris dan secara spatial kraton dan alunalun berada di ruang yang paling dalam sebagai inti, dengan pembatas berupa tembok keliling. Ditepi inti tersebut, diluar tembok keliling, terdapat masjid agung dan pasar.

Adapun situs-situs dengan nama toponimi menunjukkan jenis profesi penduduk kota-kota pemerintahan kerajaan (MataranIslam), seperti Gerjen, Kauman, Kemlayan dan Jayengan merupakan perwujudan dari permukiman bagi kelompok abdi dalem yang diperlukan untuk melayani kraton sehari-hari yang tinggal di dekat kraton, misalnya Kepatihan, Siliran dan Wirengan.

Sementara itu, keberadaan taman (Adrisijanti, 2000) selalu muncul di kota-kota pusat pemerintahan kerajaan Mataram-Islam, dengan kata lain keberadaan taman sudah menjadi tradisi. Sebagai contoh adalah Langenharjo di Surakarta dan Taman Sari di Yogyakarta. Di dalam Kraton Pleret, Yogyakarta terdapat toponimi Bale Kambang yang menyiratkan adanya taman dengan kelengkapannya berupa kolam dengan bangunan di tengahnya. Sedangkan di Surakarta, pada masa PB X dibuatlah Taman Sriwedari sebagai sarana untuk memberikan hiburan bersifat gratis bagi rakyat kecil.
KOTA SURAKARTA SEBAGAI KOTA KOLONIAL

\section{Konsep Kota Kolonial}

Pedoman dan pentunjuk teknis tata ruang dan elemen-elemen Kota Kolonial seluruhnya ditentukan oleh Pemerintah Belanda melalui pengawasan Gubernur Jendral, Residen dan para insinyur. Hal tersebut berhubungan dengan konsep kolonialisasi, berupa hubungan dominance-dependence, yaitu hubungan yang menunjukkan adanya ketergantungan antara masyarakat yang dijajah dan penjajah dengan memberikan tekanan terhadap fungsi militer dan administrasi. Hal tersebut terjadi karena bagaimanapun juga penjajah adalah kaum minoritas di negara jajahannya sehingga harus dikembangkan sistem pertahanan yang tergambar pada struktur ruang kotanya supaya masyarakat dari negara jajahan tidak berani melakukan tindakantindakan yang membahayakan mereka.

Karakteristik struktur ruang Kota Kolonial membagi ruang atas kota pribumi, kota militer dan kota sipil. Karakteristik tersebut kemudian dijabarkan ke dalam empat aspek, meliputi:

\section{Adanya "Commissioner" sebagai Pengawas \\ "Commissioner" merupakan bagian} dari institusi Pemerintah Kolonial Belanda atau dengan kata lain merupakan wakil Pemerintah Belanda di negara jajahannya. Oleh karena itu, perencanaan dan perancangan Kota Kolonial dilakukan langsung oleh Pemerintah Belanda dengan "Commissioner" sebagai pengawas pelaksananya. Namun demikian, "Commissioner" ini memiliki beberapa kewenangan di wilayah koloni, yaitu membangun benteng, mengangkat Gubernur, membentuk garnisun, membiayai perang dan membuat perjanjian damai.

\section{Adanya Tiga Jenis Bangunan Besar}

Tiga jenis bangunan besar dalam struktur tata ruang Kota Kolonial terdiri dari bangunan militer meliputi benteng, dinding pertahanan dan kanal, bangunan sipil meliputi tanggul dan jembatan, serta bangunan fasilitas perkotaaan meliputi jalan yang memisahkan blok bangunan dan petak perumahan. Selian tiga banguan besar tersebut, di beberapa wilayah Koloni ditemukan pula bangunan yang berfungsi sebagai pos dagang berisi gudang, tempat ternak, kebun sayur dan tanaman buah yang menjadi satu dengan bangunan perumahan. 
Proses pembuatan bangunan-bangunan tersebut biasanya bermula dari pembangunan pos-pos militer di wilayah Koloni. Kemudian pemaksaan terhadap aturan dan hukum yang dibuat oleh Belanda. Pembangunan Kota Kolonial masuk dalam penerapan aturan tersebut.

\section{Adanya Zonasi pada Organisasi Ruang}

Zonasi yang diterapkan pada struktur ruang Kota Kolonial umumnya menunjukkan aktivitas yang berbeda dengan fungsi-fungsi utama sebagai perumahan, pertanian, industri dan jaringan jalan, serta unit-unit yang bersifat fungsional. Sementara itu, lay out kota tersusun atas elemen dan bentuk dasar rumah tinggal, kapling lahan, lahan pertanian, jalan, alun-alun, bangunan kanal dan pelabuhan. Zonasi dan lay out dari masing-masing fungsi ruang dalam struktur ruang Kota Kolonial dibuat secara fungsional sehingga kegiatan-kegiatan yang berlangsung di dalamnya efektif dan efisien. Contohnya adalah bahwa fungsi permukiman akan berdekatan denga fungsi perdagangan, sedangkan fungsi keamanan berada di zonasi paling luar.

Dari struktur tata ruang di atas dapat dilihat bahwa sedari awal Pemerintah Kolonial Belanda sudah merencanakan bahwa tujuan utama mereka adalah berdagang namun dengan cara penjajahan untuk mengeruk kekayaan alam di Indonesia. Oleh karena itu, kota-kota kolonial selalu berada di pinggir laut ataupun sungai besar karena sistem transportasi utama pada masa itu adalah sungai dan laut. Untuk memperlancar tujuannya maka kota-kota tersebut dilengkapi dengan fasilitas bangunan kanal dan pelabuhan sebagai pendukung.

\section{Adanya Perancangan pada Ruang Publik}

Ruang publik pada Kota Kolonial dirancang sebagai satu kesatuan dengan fungsifungsi ruang yang lain sehingga hubungan diantara ruang-ruang tersebut harmoni. Sementara itu dalam hal tampak visual, ruangruang publik ini dibuat dengan melibatkan kreativitas dan seni namun tetap dengan karakter sebagai ruang publik.

\section{Kota Surakarta sebagai Kota Kolonial}

Wujud dari sistem pertahanan yang diterapkan pada Kota Kolonial maka sebagai tempat tinggal awal orang-orang Belanda di Pulau Jawa berbentuk benteng, Benteng menjadi pusat kegiatan Belanda pada masa itu. Setelah kekuasannya semakin kuat denagn terjaminnya keamanan orang-orang Belanda terhadap perlawanan rakyat, lambat laun banyak pembesar Belanda yang bermukim di luar benteng. Namun demikian, segala hal yang berhubungan dengan kegiatan pemerintahan seperti upacara resmi, menerima utusan asing maupun pesta masih berlangsung di dalam benteng.

Di Surakarta, cikal bakal berdirinya Kota Kolonial telah ada sejak didirikannya Grootmoedigheid sekitar tahun 1743, yang sekarang bernama Benteng Vastenburg. Benteng ini didirikan untuk memperkuat hegemoni kekuasaan Belanda atas kegiatan perdagangan yang berlangsung di tepi Sungai Bengawan Solo. Karena pada masa itu, Sungai Bengawan Solo menjadi lalu lintas utama bagi kegiatan perdagangan yang menghubungkan Jawa Tengah (Surakarta, Kartasura, Boyolali, Salatiga, Ungaran dan Semarang) dengan Jawa Timur (Gresik, Surabaya, Madiun, Surakarta).

Benteng dilihat dari aspek fungsi, bentuk dan lokasi berhubungan dengan perlindungan terhadap ancaman penduduk pribumi dan pedagang dari negara-negara Eropa lainnya, untuk menjamin perdagangan di Jawa. Hal ini sesuai dengan tujuan dari Pemerintah Belanda bahwa kedatangan mereka ke Indonesia adalah untuk alasan berdagang.

Di Surakarta, Benteng Grootmoedigheid berdiri terlebih dahulu dibandingkan Kerajaan Mataram Islam yang berpusat di Surakarta. Sebelum pindah ke Surakarta, pusat Kerajaan Mataram Islam terletak di Kartasura, wilayah di sisi barat Surakarta. Sementara itu, sejak tahun 1700-an Belanda sudah mulai membangun sistem perbentengan di Jawa yang dimulai dari Oetmoentinge di Ungaran, Fort Hesterlling di Salatiga, Veldwachter di Boyolali, Fort Kartosuro di Kartosuro, Fort Grootmoedigheid di Surakarta dan Fort Van Den Bosch di Ngawi. Pada ma situ pula ternyuata Surakarta sudah memiliki rancangan Kota Kolonial . Pusat kota berada di sekitar benteng dengan jalan utama (jalan milter) di sisi utara (Jalan Slamet Riyadi) jalan utama kraton yang berada di sisi selatan (Jalan Laweyan atau Jalan DR. Rajiman). Wilayah permukiman terletak di sisi utara dan timur benteng (sekarang disebut Purbayan dan Kampung Baru). Orientasi jalan utama menuju pada pusat perdagangan masa itu di Sungai Bengawan Solo yang berada di sisi timur benteng, tepatnya di Pelabuhan Nusupan dan Beton. Komoditi perdagangan dari wilayah pedalaman di bawa ke pelabuhan tersebut melalui Kali Pepe dan Kali Kabanaran. Setelah transportasi sungai surut maka peran sungai 
digantikan oleh jalan militer yang sekarang disebut Jalan Slamet Riyadi yang dilengkapi dengan jalur kereta api beserta stasiun pemberhentian dan pergudangannya. Jalurjalur kereta api dibuat masuk ke pedalaman untuk menjangkau komoditi-komoditi perdagangan di wilayah pedalaman Jawa sebelum diangkut melalui jalur laut. Setelah jalur perdagangan menggunakan Jalan Militer sebagai jalur utamanya, maka sejak saat itu pula berbagai macam fasilitas perkotaan mulai tumbuh dan berkembang di sekitar jalan tersebut. Apalagi setelah terjadi perubahan politik Pemerintah Belanda karena munculnya politik etis maka Kota Kolonial yang merupakan bentukan Belanda terbuka bagi kaum pribumi, baik untuk melakukan aktivitas maupun untuk mendirikan berbagai fasilitas. Meskipun demikian, semua tetap terbatas bagi kaum bangsawan dan Raja. Karena bagaimanapun juga keadaan ekonomi rakyat pribumi tidak akan mampu menjangkau fasilitas-fasilitas tersebut.

\section{TAMAN SRIWEDARI SEBAGAI PUSAT PENGEMBANGAN KEBUDAYAAN RAKYAT}

Taman Sriwedari merupakan taman peninggalan Paku Buwono X yang bertahta pada tahun 1893-1939, terletak di wilyah Kadipolo (Desa Talawangi). Menurut catatan RM.Ng. Tiknopranoto (mantan Asisten Wedana Onder-Distrik Gesi, Sragen) dalam bukunya Sejarah Kutho Sala (tanpa tahun), Sriwedari adalah taman untuk rekreasi (plesiran), ngenggar-enggar ati. Di dalam taman dapat ditemukan bunga-bunga dan binatang-binatang, oleh sebab itu Sriwedari disebut juga Bon Rojo. Diceriterakan bahwa Bon Rojo adalah tempat hiburan bagi rakyat, dengan tontonan bersifat tetap, yaitu wayang orang dan bioskop. Disamping itu setiap bulan puasa diadakan Maleman yang dimulai setiap malam tanggal 21 sampai dengan bakda (Lebaran puasa). Sriwedari yang dibuka tahun 1899 Masehi dilengkapi dengan toko-toko, warung dan restoran, serta pameran hasil kerajinan rakyat dan tontonan-tontonan yang lain seperti Reyog Ponorogo, Ledhek slompret, doger, kethoprak dan ludruk.

Sementara itu di sisi timur Taman Sriwedari terdapat sebuah Museum Radyapustaka yang didirikan tahun 1890. Dahulu museum tersebut adalah rumah seorang Belanda bernama Johannes Busselaar (RM. Sayid, tanpa tahun). Keberadaan Taman Sriwedari dan Museum Radyapustaka adalah atas prakarsa Patih KRA Sosrodiningrat IV. Di dalam museum ini tersimpan buku-buku Babad dan buku kuno. Selain sebagai tempat penyimpanan, Museum Radyapustaka juga menyelenggarakan pendidikan dalang (dari tahun 1923 sampai 1942), serta kursus Bahasa Kawi dan memukul gamelan.

Di sudut barat daya Taman Sriwedari dibangun rumah sakit jiwa, yang diresmikan pada tahun 1919. Rumah sakit ini diperuntukkan bagi kaum pribumi. Posisi lokasinya yang sangat dekat dan memiliki akses langsung ke Taman Sriwedari menggambarkan adanya kaitan antara keberadaan RS Jiwa Mangunjayan ini dengan fasilitas Taman Sriwedari yang pada awalnya dilengkapi dengan taman bunga, tempat rekreasi dan hiburan.

Sementara itu, di area bagian barat dari kawasan Taman Sriwedari, digambarkan oleh Rm. Ng. Tiknopranoto terdapat stadion yang dirancang oleh Mr. Zeylman sekitar tahun 1932. Area ini adalah bagian dari Taman Sriwedari yang merupakan taman bunga. Tahun 1933 stadion diresmikan oleh Sri Susuhunan Pakubuwono X yang diwakili oleh Gusti Pangeran Haryo Panular (RM. Sayid, tanpa tahun). Stadion ini dipakai untuk sepak bola dan latihan baris-berbaris abdi dalem prajurit kraton (kasunanan).

Dari posisi dan fungsi-fungsi yang dikembangkan di kawasan Taman Sriwedari, jelas fungsi-fungsi tersebut bukan lagi diperuntukkan bagi kaum bangsawan tetapi bagi rakyat. Taman Sriwedari menjadi "Pusat Kebudayaan bagi Rakyat" dan sekaligus media komunikasi antara kebudayaan kraton dan kebudayaan rakyat. Dari fungsi yang sangat penting ini tampaknya penguatan-penguatan fungsi-fungsi kebudayaan telah dikembangkan di kawasan ini sebagai pusat intelektualitas (pemikiran dan bahasa), seni (kreativitas), dan olah-kanuragan. Hal tersebut ditunjukkan oleh fasilitas-fasilitas di Taman Sriwedari seperti Museum Radya Pustaka, Stadion Sriwedari, dan Gedung Wayang Orang. Pengembangan fungsi-fungsi ini oleh Sri Susuhunan PB X menunjukkan bahwa Kota Surakarta telah memasuki babak kota modern yang tidak lepas dari pengaruh politik etis. Pembangunan dilakukan oleh pemerintah kolonial dengan merancang Kota Surakarta sebagai kota administrasi perkebunan (kantor, perbankan, hotel, jaringan kereta api, pergudangan, irigasi dan bangunan air, fasilitas pendidikan, rumah sakit, listrik dan air minum). Pembangunan pun mulai terbuka bagi masyarakat pribumi 
seperti halnya Taman Sriwedari yang sebagian besar fungsinya diperuntukkan bagi masyarakat pribumi. Di sisi lain, keterbukaan Pemerintah Belanda juga ditunjukkan pada tersebarnya fasilitas-fasilitas pribumi di pusat Kota Surakarta seperti Taman Sriwedari di Jalan Militer dan RS Kadipolo di Jalan Kraton yang letaknya tidak jauh dari Jalan Militer yang menjadi pusat orientasi Kota Kolonial di Surakarta.

Selain membuat fasilitas hiburan bagi masyarakat pribumi, PB X juga membangun sekolah-sekolah di Surakarta, mulai dari sekolah Desa (Volks School - 3 tahun) dan sekolah angka II (Tweede Inlandsche School 5 tahun). Tahun 1910 dibangun sekolah HIS (Hollandsch Inland School - 7 tahun) yang berbahasa Barat, kemudian tahun 1926 didirikan sekolah TK Pamardi Siwi dan tahun 1927 didirikan HIS Pamardi Putri. Perubahan ini tentu saja tidak terlepas dari perubahan politik Belanda terhadap negara jajahan, ketika tahun 1905 D. Fock, anggota partai Liberal yang menjadi Menteri Jajahan menyatakan bahwa dia bersedia memajukan dan meluaskan pendidikan pribumi di negara jajahan (Van Niel, 1958). Perubahan ini terjadi akibat semakin meluasnya penerapan politk etis yang bersemboyan Zaman baru adalah "kemajuan" (Shiraishi, 1990).

\section{RSJ MANGUNJAYAN}

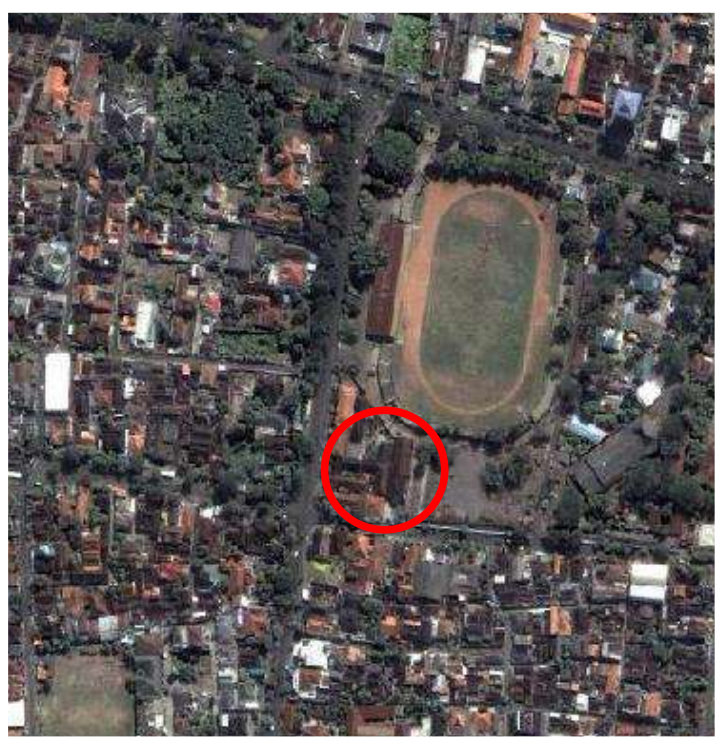

Gambar 3: Denah Lokasi RSJ Mangunjayan
Politik Etis dan Pemerataan Kesehatan di Surakarta

Posisi RSJ Mangunjayan selain erat dengan Taman Sriwedari, juga sangat dekat dengan Rumah Sakit "Panti Rogo" di Kadipolo yang dibangun oleh Susuhunan PB X. Jarak antar kedua rumah sakit itu hanya sekitar $200 \mathrm{~m}$ apabila jalan memotong pemukiman Kampung Sriwedari (lihat peta Surakarta tahun 1927). Rumah sakit "Panti Rogo" dibangun sebelum 1915 karena pada tahun 1915 telah ditemukan foto dokter dan pasien di RS ini (sumber KITLV). Rumah sakit ini kemungkinan besar dibangun sekitar tahun 1912. Rumah sakit ini pada awalnya hanya diperuntukkan bagi kerabat dan abdi dalem kraton, tetapi akhirnya juga melayani masyarakat umum pada tahun 1912-1913 karena terjadi wabah penyakit pes di Kota Surakarta dan perubahan situasi.

Berdasarkan lokasi, maka antara RSJ Mangunjayan, RS kadipolo dan Taman Sriwedari memiliki hubungan fungsional yang terkait satu dengan yang lain. Antara RSJ Mangunjayan dan RS Kadipolo memungkinkan kerjasama di bidang kesehatan, sementara itu antara RSJ Mangunjayan dengan Taman Sriwedari memungkinkan kerjasama dalam hal dukungan fasilitas rekreasi dan pelatihan fisik bagi pasien-pasiennya karena di dalam Taman Sriwedari terdapat taman-taman dan lapangan yang mendukung kegiatan-kegiatan tersebut. Di sisi lain, lokasi ketiga fasilitas tersebut memungkinkan jangkauan yang luas, artinya mereka dapat menjangkau dan melayani masyarakat dari segala penjuru kota sehingga pelayanan dapat berjalan lebih efektif. Secara politis, lokasinya strategis untuk dijangkau oleh masyarakat dari tiga penguasa, yaitu Pemerintah Kolonial, Kraton Kasunanan Surakarta dan Mangkunegaran.

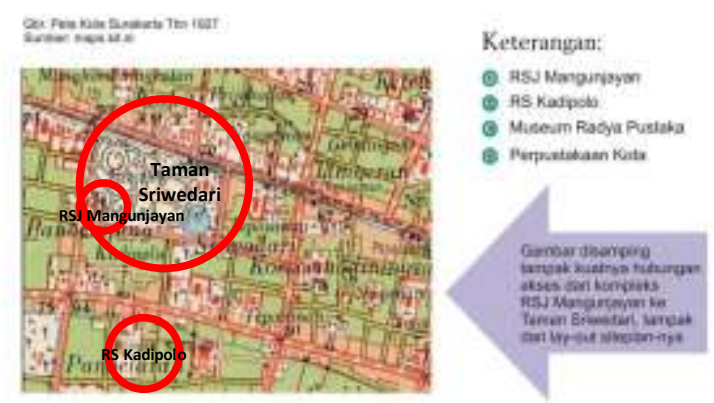

Gambar 4: Hubungan antara RSJ Mangunjayan, RS Kadipolo dan Taman Sriwedari 


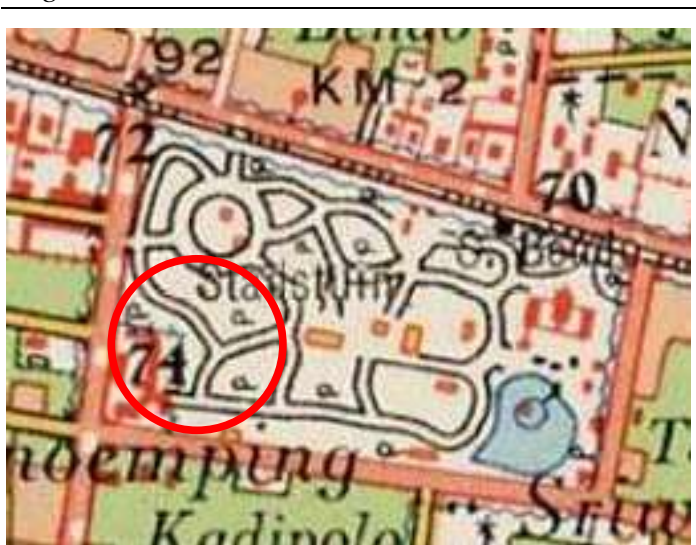

Gambar 4: Hubungan antara RSJ

Mangunjayan, RS Kadipolo dan Taman Sriwedari

Berdasarkan interpretasi peta tahun 1927 di atas, tampak bahwa antara bangunan RSJ Mangunjayan-Taman Sriwedari-Museum dan Segaran merupakan satu kesatuan keruangan yang tertata dan terencana meski periodisasi pembangunannya tidak bersamaan. Dari peta tersebut terlihat jika bangunan berdenah ' $U$ ' menghadap ke barat dengan satu buah unit bangunan di sisi barat yang merupakan RJ Mangunjayan terlihat langsung terhubung dengan jalur (path) yang berkoneksi langsung dengan Taman Sriwedari.

Dalam sejarahnya, kedua rumah sakit tersebut diperuntukkan bagi kaum pribumi. Hal tersebut merupakan gambaran bahwa politik etis mulai mempengaruhi kebijakan Pemerintah Belanda terhadap negara-negara jajahannya. Bahwa pelayanan kesehatan bukan lagi menjadi milik orang-orang Belanda, Raja dan kaum bangsawan tetapi juga menjadi milik masyarakatnya. Politik etis yang muncul pada awal abad 20 telah merubah pandangan Pemerintah Belanda pada kebijakan terhadap negara jajahan terutama dalam bidang kesehatan. Munculnya berbagai macam penyakit epidemik seperti kolera dan malaria yang terjadi hampir di semua wilayah Pulau Jawa menjadi salah satu indikasi adanya kebijakan yang salah dari Pemerintah Belanda. Oleh karena itu, diambillah kebijakan kesehatan oleh Pemerintah Belanda diantaranya adalah subsidi kesehatan pada periode 1910-1920 yang berorientasi pada perluasan pelayanan kesehatan dengan cara mendirikan banyak rumah sakit di Pulau Jawa maupun luar Jawa, baik itu milik pemerintah maupun swasta (Baha'uddin, 2006). Kebijakan kesehatan yang lain adalah pemberian sosialisasi kesehatan, yaitu bagaimana cara hidup sehat dan bagaimana penanggulangan beberapa penyakit yang bersifat epidemik. Kedua kebijakan di bidang kesehatan tersebut pada dasarnya bertujuan untuk memberikan pelayanan yang merata kepada seluruh lapisan masyarakat yang sebelumnya tidak bisa dinikmati oleh golongan masyarakat pribumi (Baha'uddin, 2006).

\section{Nilai Makna Ruang}

Dari penjelasan sejarah tersebut kita bisa memahami bagaimana posisi pelayanan kesehatan di Surakarta pada masa Kolonial Belanda. Pelayanan kesehatan pada awalnya hanya diperuntukkan kaum elit yang berorientasi pada kelompok bangsawan melalui pelayanan di Klinik Panti Rogo yang berlokasi di aksis Kraton. Kemudian berkembang menjadi pelayanan kepada masyarakat luas, berlokasi di aksis Jalan Milter (Jalan Slamet Riyadi) yang memiliki fasilitas transportasi relative lengkap dan cepat, yaitu kereta kuda dan kereta api yang dapat menjangkau sampai wilayah Hinterland. Hal ini menunjukkan bahwa pengaruh politik etis dalam kebijakan kesehatan telah mempengaruhi perkembangan perbaikan kesehatan di Surakarta. Perubahan orientasi pelayanan ini menunjukkan betapa besar pengaruh kebijakan Pemerintah Kolonial dalam perubahan makna orientasi ruang dan struktur tata ruang Kota Surakarta.

Perubahan lokasi rumah sakit dan posisinya dalam struktur dan makna ruang, menggambarkan bahwa hegemoni kekuasaan Kolonial telah mampu menggeser orientasi kehidupan dari pusat kekuasaan Kraton kepada kekuasaan Kolonial Belanda. Dari aksis Kraton sebagai pusat kekuatan sosial-ekonomi-budaya ke aksis Kota Kolonial di Jalan Milter (Jalan Slamet Riyadi). Maka dari itu, kita banyak menemukan bangunan-bangunan pemerintahan dan pelayanan umum yang dibangun diawal abad ke-20 dengan mengambil posisi dan orientasi pada kota Kolonial.

\section{KESIMPULAN}

Pertumbuhan dan perkembangan suatu kota tidak lepas dari faktor politis, ekonomis, geografis, kosmologis dan magis religius. Meskipun pada dasarnya kota memiliki ciri-ciri umum yang berhubungan dengan asal pertumbuhan, lokasi, ekologi, dan unsur sosialnya. Sementara itu, faktor-faktor ekonomi, politik, teknologi dan sosial sering dianggap menjadi dasar tumbuhnya suatu kota (Adrisijanti, 2000). 
Sebagai kota yang berawal dari bandar perdagangan di Desa Sala, Surakarta mengikuti konsep Kosmologi Jawa, dimana Kuthonegara sebagai kota raja, yaitu kota bagi raja dan keluarganya. Sementara itu, di luar kerabat raja adalah abdi dalem yang melayani semua kebutuhan hidup raja dan kerabatnya. Oleh sebab itu, konsep tata ruang kotanya bersifat mistis dan statis, ruang-ruang kota tersusun secara hierarkhis yang menggambarkan cara hidup dan relasi-relasi dalam kekuasaan keraton.

Perubahan tata-ruang sangat dipengaruhi oleh faktor kekuatan luar terutama kekuatan VOC (Kumpeni Belanda) dan Pemerintah Belanda. Dibawah kekuatan mereka, Kota Surakarta menjadi kota dengan konsep dualisme, yaitu tradisional Jawa dan Kolonial. Semua perubahan politik ini bersumber dari keputusan-keputusan di negara penjajah Belanda yang kemudian diterapkan di wilayah Hindia Belanda.

Perubahan terhadap orientasi kebudayaan yang didalamnya mempengaruhi bagaimana hubungan antara raja dan rakyatnya sangat dipengaruhi oleh munculnya kesadaran di negara jajahan akan nasib rakyat di Hindia Belanda, yaitu munculnya konsep Politik Etis di tahun 1905. Sejak saat itu di Hindia Belanda mulai muncul kesadaran dalam bentuk-bentuk pergerakan seperti Boedi Oetomo, Sarikat Islam, Muhammadiyah dan lain sebagainya. Kondisi ini kemudian berbarengan dengan munculnya wabah penyakit bersifat epidemik yang kemudian menyadarkan pihak-pihak elit dan penguasa pribumi untuk membangun perbaikan-perbaikan bagi kesejahteraan rakyat, terutama dalam bidang kesehatan dan pendidikan.

Dari catatan sejarah masa lalu yang penuh makna dengan perubahan dari masyarakat tradisional ke masyarakat modern, sangat jelas tergambar dalam goresan sejarah bangunan-bangunan di kawasan Taman Sriwedari, salah satunya adalah RSJ Mangunjayan yang terletak di bagian barat daya. Fasilitas yang dulunya hanya diperuntukkan bagi orang Belanda dan kaum bangsawan, pada saat itu sudah dapat dinikmati oleh masyarakat pribumi. Taman Sriwedari selain menjadi simbol modernisasi, juga menjadi simbol pemerataan pendidikan, kebudayaan dan kesehatan bagi masyarakat pribumi. Secara politis, Taman Sriwedari juga menjadi simbol bahwa telah terjadi perubahan orientasi Kota Surakarta, dari kraton ke Jalan Militer yang sekarang menjadi Jalan Slamet Riyadi. Hal tersebut dapat pula diartikan bahwa pada masa itu, "kekuasaan" kraton sudah terkikis sedikit demi sedikit.

\section{DAFTAR PUSTAKA}

Adrisijanti, Inajati. 2000. Arkeologi Perkotaan Mataram Islam., Yogyakarta: Jendela.

Baha'uddin, Politik Etis dan Pelayanan Kesehatan Masyarakat di Jawa pada Awal Abad XX: Studi Kebijakan Kesehatan Pemerintah Kolonial Hindia Belanda. Makalah Konferensi Nasional Sejarah VIII. $14-17$ November 2006

Muladi, Hari dkk, 1999. Runtuhnya Kekuasaan "Kraton Alit" (Studi Radikalisasi Sosial "Wong Sala" dan Kerusuhan Mei 1998 di Surakarta). Surakarta: LPTP.

Shiraishi, Takashi. 1990. Zaman Bergerak, Radikalisme Rakyat Di Jawa 19121926, (terjemahan). New York. Cornell University Press.

Solo Heritage Society (2003).Sejarah Dan Morfologi Kota Konflik: Dari Periode Kolonial-Orde Baru. (suatu hasil penelitian yang tidak/belum dipublikasikan). 